\title{
IMPLEMENTASI SAP BERBASIS AKRUAL DALAM PENYAJIAN AKUNTANSI ASET TETAP DAERAH: PRESPEKTIF OPINI BPK
}

\author{
Antin Okfitasari \\ Maksi UNS
}

\begin{abstract}
ABSTRAKSI
Implementasi Sistem Akuntansi Pemerintah melalui Standar Akuntansi Pemerintahan (SAP) berdasar PP no 71/2010 menimbulkan kesulitan bagi entitas pelaporan yang menggunakannya. Kesulitan ini dapat dilihat dari masih sedikitnya jumlah laporan keuangan unit pemerintah yang mendapat opini Wajar Tanpa Pengecualian (WTP) dari BPK. Penerapan basis akrual di Indonesia terkendala oleh beberapa hal yaitu pengembangan sistem akuntansi permerintah yang bersifat sentralis dan top down, pencatatan dan sistem inventarisir aset sebagaai dasar penyusunan aset yang masih jauh memadai, sumber daya manusia (SDM) yang kurang handal dalam pemahaman penerapan Standar Akuntansi Pemerintah (SAP). Pengawasan yang ketat perlu dilakukan sejak tahap perencanaan hingga penghapusan aset. Dalam hal ini peran masyarakat dan DPRD serta auditor internal sangat penting. Pengawasan diperlukan untuk menghindari penyimpangan dalam perencanaan maupun pengelolaan aset yang dimiliki entitas pemerintah. Implementasi akrual atas akuntansi aset tetap di pemerintah daerah masih jauh dari apa yang diharapkan. Hal ini dibuktikan dengan perbandingan opini BPK atas LKPD Provinsi pada tahun 2011. Opini WTP atas LKPD Provini hanya sebesar $36 \%$ saja dan didominasi oleh opini WDP.
\end{abstract}

Kata kunci: basis akrual, akuntansi asset, Standar kuntansi Pemerintahan. 


\section{PENDAHULUAN}

Sebuah fenomena dari bentuk reformasi sektor publik adalah hadirnya New Public Management (NPM). NPM telah mengubah konsep akuntabilitas sektor publik, NPM mendukung model sektor swasta untuk diterapkan dalam sektor publik (Christiaens et al., 2010; Lapsley et al., 2009; Hood, 1995). Carnegie dan West (2005) menyatakan bahwa perubahan dalam sektor publik dimotivasi oleh adanya harapan akuntabilitas pada sektor tersebut, dan untuk mewujudkannya aturan yang pasti harus dibuat untuk mengadopsi model berdasar keuangan sektor organisasi swasta. Sedangkan untuk meningkatkan efisiensi dan efektifitas Small Goverment tersebut, pemerintah perlu bekerja seperti layaknya dunia bisnis (swasta) dan mengadopsi praktek-praktek dan prinsip-prinsip bisnis swasta. Beberapa studi berusaha menjelaskan penerapan akuntansi berbasis akrual dalam sektor publik (Lapsley et al., 2009; Christiaens dan Rommel, 2008; Caccia dan Steccolini 2006; dan Carlin, 2005 )

Negara Indonesia telah mengadopsi pemikiran NPM dengan melakukan reformasi keuangan negara yang mulai bergulir sejak akhir tahun 2003, dengan dikeluarkannya tiga paket peraturan keuangan negara yang baru, yaitu UU No. 17 tahun 2003 tentang Keuangan Negara, Undang-Undang No.1 Tahun 2004 tentang Perbendaharaan Negara, dan UU No.15 Tahun 2005 tentang Pemeriksaan Keuangan Negara.

Implementasi sistem akuntansi berdasar akrual dalam pemerintah daerah bukanlah hal yang mudah. Implementasi Sistem Akuntansi Pemerintah melalui Standar Akuntansi Pemerintahan (SAP) berdasar PP no 71/2010 menimbulkan kesulitan bagi entitas pelaporan yang menggunakannya. Kesulitan ini dapat dilihat dari masih sedikitnya jumlah laporan keuangan unit pemerintah yang mendapat opini Wajar Tanpa Pengecualian (WTP) dari BPK. Permasalahan yang menonjol adalah kompetensi sumber daya manusia yang mumpuni dalam bidang akuntansi dan pengelolaan keuangan negara serta penyelesaian aset negara yang belum terdokumentasi dengan benar (Rasona, 2011; Hoesada, 2012).

Pada tanggal 3 Desember 2013, pemerintah melalui menteri dalam negeri Republik Indonesia menetapkan Permendagri 64 tahun 2013 tentang penerapan standar akuntansi pemerintahan berbasis akrual pada pemerintah daerah, yang diundangkan pada tanggal 6 Desember 2013, yang berlaku pada tanggal diundangkan. Dengan demikian awal tahun 2014 merupakan awal tahun penerapan akuntansi pemerintah daerah berbasis akrual. Permendagri ini berlaku bagi pemerintah daerah di level provinsi dan kabupaten/kota.

Dalam Permendagri 64 tahun 2013 ini diatur mengenai pedoman bagi pemerintah daerah dalam menerapkan Standar Akuntansi Pemerintahan berbasis akrual. Pedoman ini mencakupi panduan Kebijakan Akuntansi Pemerintah Daerah, panduan Sistem Akuntansi Pemerintah Daerah (SAPD) dan Bagan Akun Standar (BAS), mengandung implikasi praktis operasional pada tataran pemerintah daerah. Termasuk di dalamnya diatur mengenai akuntansi untuk aset tetap yang sampai saat masih menjadi masalah tahunan dalam temuan hasil pemeriksaan BPK.

Penerapan basis akrual di Indonesia terkendala oleh beberapa hal yaitu pengembangan sistem akuntansi permerintah yang bersifat sentralis dan top down, pencatatan dan sistem inventarisir aset sebagaai dasar 
penyusunan aset yang masih jauh memadai, sumber daya manusia (SDM) yang kurang handal dalam pemahaman penerapan Standar Akuntansi Pemerintah (SAP) (Robinson dan Harun 2004; Marwata dan Alam 2006; Harun 2007).

Hoesada (2007) menjelaskan bahwa selama 30 tahun dalam public sector accounting melakukan kapitalisasi aset tetap ke dalam neraca. Artinya selama ini dalam pencatatan, pengakuan dan penyajian aset tetap dalam laporan keuangan pemerintahan tidak pernah memperhatikan aspek penyusutan, sebagai alokasi manfaat ekonomis. Akibatnya penilaian aset tetap dalam neraca pemerintahan akan menjadi bias.

Siregar (2004) mengatakan pengawasan dan pengendalian, dalam pemanfaatan dan pengalihan aset merupakan suatu permasalahan yang sering terjadi pada pemerintah daerah saat ini. Suatu sarana yang efektif dalam meningkatkan kinerja aspek ini adalah melalui pengembangan SIMA (Sistem Informasi Manajemen Aset). Melalui sistem ini maka transparansi kerja dalam pengelolaan aset sangat terjamin dan dapat diawasi dengan jelas, karena keempat aspek di atas diakomodir dalam suatu sistem yang termonitor dengan jelas seperti sistem arus keuangan yang terjadi di perbankan, sehingga penanganan dan pertanggungjawaban dari tingkat pelaksana hingga pimpinan mempunyai otoritas yang jelas.

Mardiasmo (2004) menjelaskan bahwa pengawasan yang ketat perlu dilakukan sejak tahap perencanaan hingga penghapusan aset. Dalam hal ini peran masyarakat dan DPRD serta auditor internal sangat penting. Pengawasan diperlukan untuk menghindari penyimpangan dalam perencanaan maupun pengelolaan aset yang dimiliki entitas pemerintah.

Berbagai permasalahan terkait dengan implementasi akuntansi akrual dalam penyajian aset tetap di pemerintah daerah menjadi hal yang menarik untuk dijadikan isu yang perlu dibahas. Terlebih lagi dengan adanya temuan Badan Pemeriksa Keuangan (BPK) yang selalu setiap tahunnya menekankan atas penyajian aset tetap pemerintah daerah yang berakibat munculnya potensi kerugian daerah, dan pada ahkirnya berdampak pemberian opini Wajar Dengan Pengecualian bahkan Tidak Memberikan Pendapatan dikeluarkan oleh Badan Pemeriksa Keuangan. Dengan demikian, makalah ini bertujuan untuk mengetahui bagaimana implementasi akrual dalam penyajian aktiva tetap di pemerintah daerah tingkat provinsi di Indonesia melalui prespektif opini BPK. Opini BPK merupakan salah satu indikasi keberhasilan implementasi Standar Akuntansi Pemerintahan suatu entitas pemerintah.

Berdasar uraian di atas maka permasalahan yang akan dibahas dalam makalah ini adalah bagaimana implementasi akrual dalam penyajian aktiva tetap di pemerintah daerah tingkat propinsi di Indonesia dilihat dari prespektif opini BPK.

\section{LANDASAN TEORI}

\section{Basis Akrual}

Secara definisi, menurut Guthrie (1998) sistem akuntansi akrual adalah suatu metode pencatatan transaksi atas peristiwa dan pengakuan biaya (beban) berdasarkan periode terjadinya peristiwa atau transaksi tersebut. Menurut SAP akrual nomor 01 berdasar PP no 71 tahun 2010, basis akrual adalah 
Basis akuntansi yang mengakui pengaruh transaksi dan peristiwa lainnya pada saat transaksi dan peristiwa itu terjadi, tanpa memperhatikan saat kas atau setara kas diterima atau dibayar

Menurut Lundqvist (2003) dan Harun (2005) kecenderungan global untuk mengadopsi sistem akrual untuk sistem akuntansi dan peanggaran pemerintah didorong oleh negaranegara anggota OECD. Menurut laporan OECD (Lundqvist, 2003) dinyatakan bahwa keunggulan sistem akuntansi akrual banyak diakui dalam hal pengukuran implikasi ekonomi jangka pendek dan kesesuaiannya dengan pembatasan pembelanjaan, sementara kemampuan sistem berbasis kas sebagai sumber informasi untuk pengambilan keputusan dan alat pengendalian dibatasi sistem kas yang tidak melaporkan aset fisik, kas maupun utang.

Menurut Nasution (2007) akuntansi akrual memiliki beberapa manfaat yaitu mengukur biaya pelayanan jasa pemerintahan, efisiensi serta kinerja pemerintahan. Sistem akrual juga membantu pemerintah mengetahui kewajiban kontijensi pemerintah karena komitmen atau hak maupun kewajiban kontijensi pemerintah terutama untuk penerimaan dan pengeluaraan yang melampaui masa satu tahun anggaran. Dengan basis akrual maka anggaran dengan jangka panjang juga dapat lebih terkendali.

Menurut H Thompson dalam Mulyana (2006), manfaat akrual yaitu:

1. Menyediakan gambaran yang utuh atas posisi keuangan pemerintah

2. Menunjukkan bagaimana aktivitas pemerintah dibiayai dan bagaimana pemerintah dapat memenuhi kebutuhan kasnya.
3. Menyediakan informasi yang berguna tentang tingkat yang sebenarnya kewajiban pemerintah

4. Meningkatkan daya pengelolaan asset dan kewajiban pemerintah.

5. Basis akrual sangat familiar pada lebih banyak orang dan lebih komprehensif dalam penyajian informasinya.

6. Prinsip dan standar yang dapat diterima umum membentuk basis transaksi pelaporan.

7. Menyediakan data yang lebih meningkat ketika pemerintah melakukan kegiatan perencanaan dan pengambilan keputusan ekonomi.

Menurut Bastian (2010) keunggulan dasar akrual yaitu:

1. Penerimaan dan pengeluaran dalam laporan operasi berhubungan dengan penerimaan dan pemasukannya, yang berarti dasar akrual memberikan alat ukur atas barang dan jasa yang dikonsumsi. Basis Kas hanya mengukur arus keluar dan masuk atas kas.

2. Dasar akrual memberikan gambaran tentang pendapatan. Perubahan pendapatan dan besarnya biaya historis merupakan alat ukur kinerja

3. Dasar akrual dapat dijadikan alat ukur modal.

Selain memiliki keunggulan, akrual juga memiliki beberapa kelemahan. Lapsley, et al, 2009; Christiaens \& Rommel, 2008; Guthrie, 1998; Mautz, 1989; Pallot, 1990 menjelaskan adanya kelemahan penerapan basis akrual dalam sektor publik terutama dalam penilaian asetnya. Kelemahan dasar akrual menurut Bastian (2010), yaitu:

1. Kelemahan biaya historis yang digunakan dalam dasar akrual. 
2. Adanya unsur subjektivitas atas pencatatan dan pengikhtisaran pos transaksi ke dalam jurnal

3. Membutuhkan administrasi dan prosedur yang lebih rumit dibanding basis kas.

4. Peluang terjadinya manipulasi sulit dikendalikan dibandingkan jika menggunakan dasar kas.

Dalam sistem akrual, pencatatan biaya depresiasi suatu asset dibebankan ke periode waktu selama suatu aset tersebut digunakan berdasarkan biaya harga pembelian aset. Sedangkan menurut sistem akuntansi berbasis kas, biaya pengadaan aset tersebut dibebankan ke periode saat dilakukan pembayaran atas harga aset.

Isu tentang pentingnya waktu (timing) dalam pengakuan (recognition) suatu transaksi atau peristiwa ekonomi merupakan hal yang sangat penting dalam suatu lingkungan sistem akrual, sehingga lebih membantu dalam meningkatkan akuntabilitas dan pengambilan keputusan. Karena angka-angka akuntansi berdasarkan sistem akrual dianggap lebih informatif, membawa implikasi yang signifikan untuk pimpinan sektor publik dalam mengalokasikan sumber daya yang dimiliki. Dengan demikian adopsi akuntansi akrual mengarahkan pelaksanaan program dan aktifitas suatu agen sektor publik untuk senantiasa mempertimbangkan prinsip dan pengukuran transaksi, peristiwa serta kinerja aktivitas organisasi pemerintah berdasarkan substansi operasional ketimbang fokus pada kapan dan berapa penerimaan dan pembelanjaan kas yang dilakukan pemerintah. Situasi seperti itu mendorong aspek relevansi, netralitas, ketepatan waktu, kelengkapan dan komparabilitas kinerja keuangan suatu agen sektor publik menjadi perhatian para pimpinan organisasi pemerintah.

\section{Sistem Akuntansi Aset}

Laporan asset tetap diperlukan untuk pengendalian dan pengambilan keputusan terkait dengan investasi serta penilaian pemanfaatan sumber daya yang dimiliki pemerintah daerah. Standar Akuntansi Pemerintahan dalam PSAP 07 menjelaskan berbagai hal terkait dengan definisi, pengakuan dan pengukuran aktiva tetap. SAP no 7 mendefinisikan aset adalah

Sumber daya ekonomi yang dikuasai dan/atau dimiliki oleh pemerintah sebagai akibat dari peristiwa masa lalu dan dari mana manfaat ekonomi dan/atau sosial di masa depan diharapkan dapat diperoleh, baik oleh pemerintah maupun masyarakat, serta dapat diukur dalam satuan uang, termasuk sumber daya nonkeuangan yang diperlukan untuk penyediaan jasa bagi masyarakat umum dan sumber-sumber daya yang diperlihara karena alasan sejarah dan budaya.

Definisi aset tetap dalam PSAP 07 dijelaskan

Aset tetap adalah aset berwujud yang mempunyai masa manfaat lebih dari 12 (dua belas) bulan untuk digunakan, atau dimaksudkan untuk digunakan,dalam kegiatan pemerintah atau dimanfaatkan oleh masyarakat umum.

Dalam Permendagri 64 tahun 2013 diatur mengenai kebijakan akuntansi aset tetap mencakup

1. Peraturan daerah mengenai nilai satuan minimum yang dapat dikapitalisasi setiap jenis aset termasuk aset tetap, yaitu sebesar satu juta rupiah.

2. Peraturan daerah tentang kapitalisasi jenisjenis aset tanpa batas minimum kapitalisasi, seperti tanah, jalan, irigasi, jaringan, koleksi perpustakaan, benda budaya, sarana mengajar pemerintah daerah 
3. Peraturan daerah yang menjelaskan, memberikan batas minimum dan memberi contoh pengeluaran setelah perolehan atau pembuatan /konstruksi/pembangunan sendiri aset tetap yang menambah manfaaat ekonomis seperti adanya renovasi dan modifikasi sehingga harus dikapitalisasi, misalnya batas minimum sebesar dus puluh juta rupiah.

4. Peraturan daerah yang menjelaskan nama aset tetap yang disusutkan dan estimasi masa manfaat ekonomi tiap jenis aset tetap. Penyajian meliputi kode akun tiap jenis aktiva tetap, uraian nama tiap kelompok aset tetap, penetapan masa manfaat tiap jenis aset, dan masa residu paska penyusutan paripurna diharuskan nihil sehingga hasil pelepasanpenjualan aset diakui pendapatan.

Sementara itu, pengertian aset secara umum menurut Siregar (2004: 178) adalah barang (thing) atau sesuatu barang (anything) yang mempunyai nilai ekonomi (economic value), nilai komersial (commercial value) atau nilai tukar (exchange value) yang dimiliki oleh badan usaha, instansi atau individu (perorangan). Istilah properti seringkali melekat dengan istilah lain untuk memberikan pengertian yang lebih jelas secara hukum, yaitu real estate dan real property dimana keduanya mempunyai makna yang berbeda meskipun ada juga yang menyebutnya sebagai sinonim dalam lingkup tertentu. Selanjutnya, Real estate is the physical land and appurtenances affixed to the land, e.g., structure. Real estate bersifat tidak bergerak (immobile) dan berwujud (tangibel), yang termasuk dalam pengertian ini adalah tanah, semua benda yang secara alami sebagai bagian dari tanah, seperti pepohonan dan barang mineral dan juga segala sesuatu yang dibangun oleh manusia seperti bangunan, jaringan dan lain sebagainya.

Untuk mencapai tujuan pengelolaan aset secara terencana, terintegrasi, dan sanggup menyediakan data dan informasi yang dikehendaki dalam tempo yang singkat, diperlukan suatu sistem informasi pendukung pengambilan keputusan atas aset (decision supporting system), yang disebut sebagai Sistem Informasi Manajemen Aset (Siregar, 2004). Mardiasmo (2004) menjelaskan untuk pengelolaan aset daerah secara efesien dan efektif serta menciptakan transparansi kebijakan pengelolaan aset daerah, maka pemerintah daerah perlu memiliki atau mengembangkan sistem informasi manajemen yang komprehensif dan handal sebagai alat pengambilan keputusan. Sistem tersebut bermanfaat untuk menghasilkan laporan pertanggungjawaban, selain itu juga bermanfaat untuk dasar pengambilan keputusan mengenai kebutuhan pengadaan barang dan estimasi kebutuhan belanja pembangunan (modal) dalam penyusunan APBD

Siregar (2004) menjelaskan bahwa pengawasan dan pengendalian aset tetap dapat dilakukan dalam lima tahapan yaitu

a) Inventarisasi aset

Berdasarkan Peraturan Pemerintah Republik Indonesia Nomor 6 Tahun 2006 tentang Pengelolaan Barang Milik Negara/Daerah dan Peraturan Menteri Dalam Negeri Nomor 17 Tahun 2007 tentang Pedoman Teknis Pengelolaan Barang Milik Daerah, menjelaskan bahwa inventarisasi adalah kegiatan untuk melakukan pendataan, pencatatan, dan pelaporan hasil pendataan barang milik

b) Legal Audit

Siregar (2004) mengatakan legal audit, merupakan suatu ruang lingkup untuk 
mengidentifikasi dan mencari solusi atas permasalahan legal mengenai prosedur penguasaan atau pengalihan aset seperti status hak penguasaan yang lemah, aset yang dikuasai pihak lain, pemindahan aset yang tidak termonitor dan lain-lain

c) Penilaian aset

Berdasarkan Peraturan Pemerintah Republik Indonesia Nomor 6 Tahun 2006 tentang Pengelolaan Barang Milik Negara/Daerah dan Peraturan Menteri Dalam Negeri Nomor 17 Tahun 2007 tentang Pedoman Teknis Pengelolaan Barang Milik Daerah, penilaian adalah suatu proses kegiatan penelitian yang selektif didasarkan pada data/fakta yang obyektif dan relevan dengan menggunakan metode/teknis tertentu untuk memperoleh nilai barang milik daerah. Dalam rangka menyusun neraca pemerintah perlu diketahui berapa jumlah aset negara sekaligus nilai dari aset tersebut. Untuk diketahui nilainya maka barang milik negara secara periodik harus dilakukan penilaian baik oleh pengelola barang ataupun melibatkan penilai independent sehingga dapat diketahui nilai barang milik negara secara tepat. Untuk penilaian berupa tanah dan atau bangunan menggunakan patokan Nilai Jual Obyek Pajak (NJOP).

Menurut Siregar (2004) penilaian aset merupakan suatu proses kerja untuk melakukan penilaian atas aset yang dikuasai. Untuk itu pemerintah daerah dapat melakukan outsourcing kepada konsultan penilai yang profesional dan independent. Hasil dari nilai tersebut akan dimanfaatkan untuk mengetahui nilai kekayaan maupun informasi untuk penetapan bagi aset yang akan dijual

d) Optimalisasi aset
Berdasarkan Peraturan Pemerintah Republik Indonesia Nomor 6 Tahun 2006 tentang Pengelolaan Barang Milik Negara/Daerah dan Peraturan Menteri Dalam Negeri Nomor 17 Tahun 2007 tentang Pedoman Teknis Pengelolaan Barang Milik Daerah, pemanfaatan adalah pendayagunaan barang milik daerah yang tidak dipergunakan sesuai dengan tugas pokok dan fungsi Satuan Kerja Perangkat Daerah (SKPD) dalam bentuk sewa, pinjam pakai, kerjasama pemanfaatan, bangun guna serah dan bangun serah guna dengan tanpa mengubah status kepemilikan

e) Pengembangan SIMA

Siregar (2004) mengatakan pengawasan dan pengendalian, dalam pemanfaatan dan pengalihan aset merupakan suatu permasalahan yang sering terjadi pada pemerintah daerah saat ini. Suatu sarana yang efektif dalam meningkatkan kinerja aspek ini adalah melalui pengembangan SIMA (Sistem Informasi Manajemen Aset). Melalui sistem ini maka transparansi kerja dalam pengelolaan aset sangat terjamin dan dapat diawasi dengan jelas, karena keempat aspek di atas diakomodir dalam suatu sistem yang termonitor dengan jelas seperti sistem arus keuangan yang terjadi di perbankan, sehingga penanganan dan pertanggungjawaban dari tingkat pelaksana hingga pimpinan mempunyai otoritas yang jelas.

Salah satu hal mendasar dalam masalah akuntansi aset tetap adalah penyusutan atas aktiva tetap. Menurut Standar Akuntansi Pemerintahan 07 dijelaskan penyusutan adalah

Alokasi yang sistematis atas nilai suatu aset tetap yang dapat disusutkan selama masa manfaat aset yang bersangkutan

Menurut Hoesada (2007) menjelaskan bahwa selama 30 tahun dalam public sector 
accounting melakukan kapitalisasi aset tetap ke dalam neraca. Artinya selama ini dalam pencatatan, pengakuan dan penyajian aset tetap dalam laporan keuangan pemerintahan tidak pernah memperhatikan aspek penyusutan, sebagai alokasi manfaat ekonomis. Akibatnya penilaian aset tetap dalam neraca pemerintahan akan menjadi bias.

Hoesada (2007) menjelaskan terdapat beberapa alasan pentingnya dilakukan depresiasi atas aktiva tetap di sektor pemerintahan, yaitu

1. Maching biaya dan manfaat yang layak daam akuntansi akrual penuh

2. Daya prediksi kebutuhan aktiva tetap di masa depan

3. Pertanggungjawaban laporan keuangan pemerintah ke legislatif harus purna

4. Laporan keuangan menyajikan informasi tambahan tentang kinerja entitas

5. Penyusutan menghasilkan neraca yang tidak overstated

6. Pengukuran solvabilitas menjadi lebih objektif bila menggunakan nilai buku aktiva tetap dalam neraca

7. Penyusutan tidak dapat diganti dengan impairment dan revaluation

8. Pertanggungjawaban penggunaan penuh kapasitas tersedia

9. Ketika anggaran masih berbasis kas, maka sebaiknya akuntansi tetap akrual sehingga depresiasi harus dilakukan

10. Tanpa adanya depresiasi, maka akan muncul besar pasak daripada tiang

11. Terdapat kesulitan dalam memperbandingkan laporan keuangan antar entitas karena pengakuan aktiva tetap memasukan sewa aktiva tetap dan pembelian aktiva tetap.
12. Penyusutan adalah akuntansi untuk keselamatan publik, bila aktiva tetap dipergunakan untuk layanan publik atau wilayah publik.

13. Neraca politik : bahwa neraca merupakan teknologi menabung lintas tahun bahkan lintas kabinet untuk belanja modal dipandu oleh teknologi penyusutann dan sisa umur aktiva tetap.

14. Kembali ke akuntansi dasar

15. Manajemen pemerintahan modern

16. Akuntabilitas atas biaya tetap atau subsidi pemerinta

17. Pengukuran kinerja aktiva tetap

18. Database akuntansi aktiva tetap dan penyusutan digunakan untuk akuntansi biaya

19. Pentingnya pengetahuan atas aset yang dikelola

20. Aktiva tetap adalah objek audit BPK

21. Perubahan sistem pengendalian kepatuhan berubah ke sistem pengendalian kinerja

22. Dari akuntabilitas menjadi pengambilan keputusan berdasar akuntansi dan pelaporan

23. Informasi surplus APBN dilengkapi informasi surplus ekuitas

24. Kebutuhan informasi Dewan Perwakilan Rakyat

25. Dalam UU no 17 tentang keuangan negara, dijelaskan bahwa aset tetap merupakan bagian dari keuangan negara

Dengan melihat alasan tersebut di atas, maka dapat disimpulkan bahwa penyusutan menjadi hal yang penting untuk dilaksanakan untuk mencapai akuntanbilitas ke publik maupun para stakeholder pemerintah. Dengan menerapkan penyusutan atas aktiva tetap maka laporan keuangan akan menunjukan kualitas yang lebih baik. 
Standar Akuntansi Pemerintahan membolehkan penggunaan beberapa metode penyusutan seperti metode garis lurus, metode saldo memurun ganda, dan metode unit produksi. Nilai penyusutan untuk masing-masing periode diakui sebagi pengurang nilai tercatat aset tetap dalam neraca dan beban penyusutan disajikan dalam laporan operasional.

Berbeda dengan Standar Akuntansi Pemerintahan berdasar PP no 71 tahun 2010, dalam Permendagri nomor 64 tahun 2013, hanya membolehkan metode penyusutan garis lurus tanpa nilai residu. Kebijakan akuntansi pos laporan keuangan dan akun buku besar aset tetap pemerintah daerah hendaknya mengambil hikmah PSAP, Bultek Neraca Awal Akrual Paripurna, Bultek Aset Tetap dan Penyusutan Aktiva Tetap Akrual Paripurna, Bultek Hibah dan Bultek Kerugian Negara.

Pemerintah daerah dalam menetapkan kebijakan akuntansi aset tetap perlu berhati-hati dan mewaspadai beberapa hal berikut:

a. Kebijakan tentang pembentukan dan akuntansi Buku Pembantu Buku Besar Aset Tetap (subsidiary ledger) berdasar nama aset dan lokasi;

b. Konstruksi dalam pengerjaan;

c. Bunga masa konstruksi;

d. Pembedaan serta pengklasifikasian aset berwujud dan tidak berwujud,;

e. Dasar pertimbangan dan metode penentuan umur ekonomis tiap kelompok jenis aset berterima BPK;

f. Pembuktian harga beli wajar berterima BPK (prosedur tender, tim seleksi, harga pasar tanah, spesifikasi dan gambar teknis, kualitas direksi veering, dll);

g. Bukti kas keluar ter-apropriasi (terjatah, teralokasi) untuk proyek khusus tertentu; h. Kebijakan Kapitalisasi pengeluaran pengadaan baru atau konstruksi sendiri (misalnya dalam bentuk daftar jenis dan nilai kapitalisasi minimum tiap jenis aset tetap atau ATB);

i. Kebijakan Kapitalisasi tanpa Batas Minimum (misalnya buku pustaka pemda, flora dan fauna hias, misalnya ikan Arwana, dll), benda seni, barang antik, pusaka pemda, dll);

j. Kebijakan Kapitalisasi Dalam Bentuk Penambahan Nilai Terbawa Aset Renovasian;

k. Kebijakan Penghibahan Aset Tetap (misalnya dasar pertimbangan hibah keluar;

1. Kebijakan Politik dan Syarat Hibah Yang Boleh Diterima Pemerintah Daerah (misalnya hibah bersyarat politik dan/atau hibah dari pihak-pihak tertentu yang tidak boleh diterima oleh Pemda);

m. Kebijakan hapus buku aset tetap (derognition, write off), hapus buku dan akuntansi kehilangan (KKN, Kerugian Negara) dan hapus buku dan penurunan nilai aset (impairment) akibat kerusakan/kemusnahan aset tetap (gempa bumi,kebakaran, banjir, tabrakan dll);

n. Kebijakan akuntansi pos Laporan Keuangan dan akun Buku Besar Aset Tidak Berwujud hendaknya mengambil hikmah PSAP dan Bultek Aset Tidak Berwujud. Waspadai berbagai hal serupa namun tidak sepenuhnya sama dengan dimensi perda aset tetap tersebut di atas, ditambah kebijakan kewajiban evaluasi berkala (minimum pada tanggal neraca) keusangan teknologi aset tidak berwujud yang sebaiknya dihapus buku (misalnya sarana perangkat lunak). 
Penyajian Aset Tetap Menurut PP No 71 Tahun 2010

Aset tetap sering merupakan bagian utama dalam aset pemerintah. Aset tetap menjadi bagian signifikan dalam penyajian neraca pemerintah daerah (SAP 07 para 5). Dalam SAP 07 dijelaskan pengklasifikasian aset teap didasarkan atas kesamaan dalam sifat dan fungsinya dalam aktivitas operasi entitas. Klasifikasi aset tetap terdiri dari tanah, peralatan dan mesin, gedung dan bangunan, jalan, irigasi dan jaringan, aset tetap lainnya serta konstruksi dalam pengerjaan.

Pengakuan aset tetap diakui ketika manfaat ekonomi masa depan dapat diperoleh dan nilainya dapat diukur dengan handal. Kriteria yang ditetapkan dalam SAP 07 untuk dapat diakui sebagai aset tetap, meliputi:

a) Berwujud

b) Mempunyai masa manfaat lebih dari dua belas bulan

c) Biaya perolehan aset dapat diukur secara andal

d) Tidak dimaksudkan untuk dijual dalam operasi normal entitas

e) Diperoleh atau dibangun dengan maksud untuk digunakan

Pengukuran aset tetap dinilai dengan nilai perolehan, ketika nilai perolehan tidak diperoleh maka pengukuran aset tetap didasarkan atas nilai wajar pada saat perolehan.

Pemerintah menginvestasikan dana yang besar dalam bentuk asset yang tidak secara langsung menghasilkan pendapatan bagi pemerintah, seperti gedung perkantoran, jembatan, jalan, taman, dan kawasan reservasi. gram pemeliharaan dan rehabilitasi yang memadai diperlukan untuk Sebagian besar aset dimaksud mempunyai masa manfaat yang lama sehingga promempertahankan manfaat yang hendak dicapai. Dengan demikian, fungsi aset dimaksud bagi pemerintah berbeda dengan fungsinya bagi organisasi komersial. Sebagian besar aset tersebut tidak menghasilkan pendapatan secara langsung bagi pemerintah, bahkan menimbulkan komitmen pemerintah untuk memeliharanya di masa mendatang. Aset yang digunakan pemerintah, kecuali beberapa jenis aset tertentu seperti tanah, mempunyai masa manfaat dan kapasitas yang terbatas. Seiring dengan penurunan kapasitas dan manfaat dari suatu aset dilakukan penyesuaian nilai (Setyaningsih, 2012).

Prinsip pengungkapan lengkap (full disclosure) adalah laporan keuangan menyajikan secara lengkap informasi yang dibutuhkan oleh pengguna. Informasi yang dibutuhkan oleh pengguna laporan keuangan dapat ditempatkan pada lembar muka (on the face) laporan keuangan atau Catatan atas Laporan Keuangan. Pengungkapan meliputi dasar penilaian yang digunakan untuk menentukan nilai tercatat, rekonsiliasi jumlah tercatat pada awal dan ahkir periode, informasi penyusutan, eksistensi dan batasan hak milik atas aset tetap, kebijakan akuntansi untuk kapitalisasi yang berkaitan dengan aset tetap, jumlah pengeluaran pada pos aset tetap dalam konstruksi serta jumlah komitmen untuk akuisisi aset tetap. Terkait dengan pengungkapan aset bersejarah diungkapkan secara rinci, meliputi nama, jenis, kondisi dan lokasi aset bersejarah.

\section{Opini BPK}

Sebagaimana dijelaskan dalam IHPS I tahun 2012, pemberian opini BPK atas laporan keuangan suatu entitas didasarkan atas beberapa pertimbangan, yaitu 
1. Kesesuaian dengan Standar Akuntansi Pemerintah

SAP merupakan pedoman yang digunakan sebagai prinsip akuntansi yang berlaku umum di Indonesia untuk semua entitas pemerintahan. SAP yang pergunakan adalah SAP berdasar PP no 71 tahun 2010 telah ditetapkan.

2. Efektifitas Sistem Pengendalian Intern Pemeriksaan atas efektifitas SPI didasarkan atas PP no 60 tahun 2008. SPI meliputi lingkungan pengendalian, penilaian resiko, kegiatan pengendalian, informasi dan komunikasi serta pemantauan. SPI dinyatakan efektif apabila mampu memberikan keyakinan yang memadai atas tercapainya efektifitas dan efisiensi pencapaian tujuan entitas keandalan pelaporan keuangan, keamanan aset negara dan kepatuhan terhadap peraturan perundang-undangan yang berlaku. Kelemahan SPI merupakan temuan BPK yang merupakan suatu "kasus" di bagi menjadi tiga katagori yaitu (1) kelemahan sistem pengendalian akuntansi (pencatatan akuntansi dan pelaporan); 2) kelemahan sistem pengendalian pelaksanaan Anggaran Belanja dan Pendapatan (Pemungutan dan Penyetoran Penerimaan Negara/Daerah, pelaksanaan program atas entitas yang diperiksa) (3) kelemahan SPI (ada tidaknya struktur pengendalian intern, efektifitas struktur pengendalian intern).

3. Kepatuhan terhadap perundang-undangan Opini didasarkan atas kepatuhan entitas pemerintah terhadap peraturan perundangundangan yang berlaku. Atas hasil pemeriksaan akan menghasilkan temuan yang dikatagorikan dalam kerugian negara, potensi kerugian negara, kekurangan penerimaan, administrasi, ketidakekonomisan, ketidakefisienan dan ketidakefektifan.

Menurut Undang-undang no 15 tahun 2004 tentang Pemeriksaan Pengelolaan dan Tanggung Jawab Keuangan Negara, BPK memberikan empat opini atas laporan keuangan entitas, yaitu :

1. Pendapat Wajar Tanpa Pengecualian (WTP/ Unqualified Opinion)

Adalah suatu pendapat yang menyatakan bahwa laporan keuangan pemerintah yang diperiksa menyajikan secara wajar dalam semua hal yang material.ys Kas, Neraca, dan Catatan atas Laporan Keuangan sesuai dengan prinsip akuntansi yang berlaku umum di Indonesia (SAP). Opini ini diberikan oleh BPK, ketika BPK meyakini berdasar bukti-bukti audit yang dikumpulkan, pemerintah derah dianggap telah menyelenggarakan prinsip akuntansi yang berlaku dengan baik, kalaupun terdapat ada kesalahan, kesalahan ini dianggap bersifat tidak material dan tidak secara signifikan berpengaruh terhadap pengambilan keputusan pengguna laporan keuangan.

2. Pendapat Wajar Dengan Pengecualian (WDP/Qualified Opinion)

Adalah pendapat yang menyatakan bahwa laporan keuangan pemerintah daerah yang diperiksa menyajikan wajar dalam semua hal yang material. Laporan Keuangan meliputi LRA, Laporan Arus Kas, Neraca dan Catatan atas Laporan Keuangan sesuai dengan prinsip akuntansi yang berlaku umum di Indonesia (SAP), kecuali untuk dampak hal-hal yang berhubungan dengan 
yang dikecualikan. Ketidakwajaran yang muncul tidak mempengaruhi secara keseluruhan laporan keuangan.

3. Pendapat Tidak Wajar (TW/Adverse Opinion)

Adalah suatu pendapat yang menyatakan bahwa laporan keuangan yang diperiksa tidak disajikan secara wajar. Laporan keuangan meliputi LRA, Laporan Arus Kas, Neraca dan Catatan atas Laporan Keuangan tidak disajikan secara wajar sesuai dengan prinsip akuntansi yang berlaku umum di Indonesia. Jika opini ini dikeluarkan oleh BPK, berarti BPK meyakini bahwa laporan keuangan yang disajikan diragukan kebenarannya, sehingga dapat menyesatkan pengguna laporan keuangan dalam pengambilan keputusan.

4. Pernyataan Menolak Memberikan Pendapat (TMP/ Disclaimer Opinion)

Adalah pendapat yang menyatakan bahwa auditor tidak menyatakan pendapat atas laporan keuangan yang diperiksa.
Pertimbangannya adalah ketidakcukupan buktipemeriksaan untuk dibuat kesimpulan oleh BPK. Pertimbangan lain adalah adanya pembatasan ruang lingkup pemeriksaan yang dilakukan oleh pemerintah daerah yang diperiksa.

\section{PEMBAHASAN}

Berdasar Ikhtisar Hasil Pemeriksaan Semester (IHPS) I tahun 2012, diperoleh hasil pemeriksaan dari BPK berupa opini atas pemerintah daerah provinsi di Indonesia. Opini BPK merupakan salah satu indikator keberhasilan implementasi akrual berdasar SAP yang telah ditetapkan pemerintah. Di bawah ini tabel yang menunjukan perkembangan opini BPK atas Laporan Keuangan Pemerintah Daerah tingkat Provinsi: Opini BPK atas Pemerintah Provinsi

\begin{tabular}{|c|r|r|r|c|r|r|r|r|r|}
\hline \multirow{2}{*}{ Thn LK } & \multicolumn{7}{|c|}{ Opini } & \multirow{2}{*}{ Jumlah } \\
\cline { 2 - 10 } & WTP & $\%$ & WDP & $\%$ & TW & $\%$ & TMP & $\%$ & \\
\hline 2006 & 0 & $0 \%$ & 25 & $76 \%$ & 4 & $12 \%$ & 4 & $12 \%$ & 33 \\
\hline 2007 & 1 & $3 \%$ & 21 & $64 \%$ & 3 & $9 \%$ & 8 & $24 \%$ & 33 \\
\hline 2008 & 0 & $0 \%$ & 24 & $73 \%$ & 1 & $3 \%$ & 8 & $24 \%$ & 33 \\
\hline 2009 & 1 & $3 \%$ & 24 & $73 \%$ & 3 & $9 \%$ & 5 & $15 \%$ & 33 \\
\hline 2010 & 6 & $18 \%$ & 22 & $67 \%$ & 0 & $0 \%$ & 5 & $15 \%$ & 33 \\
\hline 2011 (Smt 1) & 10 & $36 \%$ & 16 & $57 \%$ & 0 & $0 \%$ & 2 & $7 \%$ & 28 \\
\hline
\end{tabular}

Sumber : IHPS I Tahun 2012

Dari tabel di atas tampak bahwa terdapat peningkatan penyajian LKPD Provinsi sejak tahun 2006. Perkembangan peningkatan prosentase opini Wajar Tanpa Pengecualian (WTP) di tahun 2006 dibandingkan di tahun 2010 mengalami peningkatan sebesar 10\%. Jika

dibandingkan dengan hasil pemeriksaan tahun 2012 semester I menunjukan peningkatan sebesar 36\%. Akan tetapi jika dianalisis lebih lanjut mayoritas opini atas LKPD Provinsi lebih didominasi oleh opini Wajar Dengan Pengecualian (WDP), bahkan masih terdapat 
provinsi yang laporan keuangannya masih mendapat opini Tidak Mengeluarkan Pendapat (TMP) sebanyak 2 provinsi yaitu Maluku Utara dan Papua.

Pemberian opini atas LKPD didasarkan atas beberapa pertimbangan meliputi:

1. Kesesuaian dengan Standar Akuntansi Pemerintah

2. Efektifitas Sistem Pengendalian Intern

3. Kepatuhan terhadap perundang-undangan Perolehan opini WDP yang lebih mendominasi di pemerintah provinsi menurut BPK yang dituangkan dalam IHPS I tahun 2012 disebabkan oleh masalah pengelolaan kas, persediaan, investasi permanen dan non permanen serta aset tetap. Pemeriksaan yang dilakukan BPK meliputi keempat pertimbangan di atas.

\section{Kesesuaian dengan Standar Akuntansi Pemerintah}

Menurut Rasono (2011), selama tahun 2005 sampai dengan 2009 laporan keuangan pemerintah daerah didasarkan atas basis kas dan akrual untuk penyusunan neraca. Tahun 2010 dan 2011 menggunakan basis akrual sebagaimana PP no 71 tahun 2010, yaitu kecuali untuk LRA semua laporan keuangan disusun berdasarkan basis akrual. Akan tetapi untuk tahun 2010 sampai dengan 2014, jika entitas pelaporan belum mampu melaksanakan basis akrual, maka basis yang digunakan adalah basis kas menuju akrual. Dengan demikian, selama ini pemerintah daerah masih menggunakan basis kas menuju akrual sebagaimana basis yang ditetapkan dalam SAP berdasar PP no 24 tahun 2005.

Tabel diatas menunjukan indikator kualitas laporan keuangan yang disajikan oleh pemerintah daerah yang diukur dari Standar Akuntansi Pemerintah. Terdapat peningkatan yang cukup bagus dari tahun ke tahun atas kualitas penyajian laporan keuangan pemerintah provinsi, akan tetapi jumlah pemerintah provinsi yang memperoleh opini WDP lebih mendominasi dari tahun ke tahun. Hal ini menjadi perhatian khusus bagi pemerintah provinsi untuk terus memahami dan mengupayakan pemahaman atas Standar Akuntansi Pemerintah. Terlebih dengan diterbitkannya Permendagri no 64 tahun 2013, pemerintah propinsi harus lebih memahami pedoman penyusunan laporan keuangan pemerintah daerah. Dengan pemahaman atas permendari ini diharapkan akan men-drive penerapan SAP yang benar, sehingga diperoleh opini Wajar Tanpa Pengecualian.

\section{Efektifitas Sistem Pengendalian Intern}

Hasil pemeriksaan tahun 2011 menunjukan bahwa LKPD yang memperoleh opini WTP dan WDP umumnya memiliki Sistem Pengendalian Intern yang memadai. Untuk LKPD yang memperoleh opini TMP dan TW perlu melakukan perbaikan pengendalian intern dalam hal penilaian resiko, kegiatan pengendalian dan pemantauan. Hasil evaluasi atas LKPD menunjukan kasus kelemahan SPI sebagaimana tabel di bawah ini: 
Kelompok Temuan SPI atas Pemeriksaan LKPD tahun 2011

\begin{tabular}{|l|l|l|}
\hline No & Kelompok Temuan & $\begin{array}{l}\text { Jumlah } \\
\text { Kasus }\end{array}$ \\
\hline 1 & $\begin{array}{l}\text { Kelemahan Sistem Pengendalian Akuntansi dan } \\
\text { Pelaporan }\end{array}$ & 1.791 \\
\hline 2 & $\begin{array}{l}\text { Kelemahan Sistem Pengendalian Pelaksanaan Anggaran } \\
\text { Pendapatan dan Belanja }\end{array}$ & 1.739 \\
\hline 3 & Kelemahan Struktur Pengendalian Intern & 839 \\
\hline & Jumlah & 4.369 \\
\hline
\end{tabular}

Sumber IHPS I tahun 2012

a. Kelemahan atas sistem pengendalian akuntansi dan pencatatan terdiri atas :

1. Sebanyak 1.005 kasus pencatatan tidak /belum dilakukan atau tidak akurat.

2. Sebanyak 603 kasus proses penyusunan laporan tidak sesuai dengan ketentuan

3. Sebanyak 13 entitas terlambat menyampaikan laporan

4. Sebanyak 147 kasus sistem informasi akuntansi dan pelaporan tidak memadai

5. Sebanyak 23 kasus sistem informasi akuntansi dan pelaporan belum didukung SDM memadai.

Contoh kasus terkait dengan aset tetap yaitu: di salah satu kabupaten di Jawa Tengah, terdapat aset tetap yang disajikan dalam neraca per 31 Desember 2011 tidak didasarkan atas pencatatan yang memadai dan beberapa aset tanah belum dicatat. Akibatnya adalah nilai aset tetap tidak akurat dan belum mencerminkan aset tetap yang dimilik pemerintah daerah.

b. Kelemahan Sistem Pengendalian Pelaksanaan Anggaran Pendapatan dan Belanja, kasus yang ditemukan terdiri dari :
1. Sebanyak 577 kasus perencanaan kegiatan tidak memadai

2. Sebanyak 249 kasus mekanisme pemungutan, penyetoran dan pelaporan serta penggunaan penerimaan daerahdan hibah tidak sesuai ketentuan

3. Sebanyak 494 kasus penyimpangan terhadap peraturan perundang-undangan bidang teknis tertentu atau ketentuan intern organisasi yang diperiksa tentang pendapatan dan belanja

4. Sebanyak 97 kasus peaksanaan belanja di luar mekanisme APBD

5. Sebanyak 237 kasus pelaksanaan kebijakan tidak tepat atau belum dilaksanakan berakibat hilangnya potensi penerimaan /pendapatan

6. Sebanyak 80 kasus penetapan/pelakanaan kebijakan tidak tepat atau belum dilakukan berakibat peningkatan belanja

7. Sebanyak 5 kasus dikarenakan adanya pengelolaan dan pengamanan fisik aset yang tidak memadai.

Misalnya di Provinsi Jawa Barat, pekerjaan pembangunan pasar dalam tahun jamak yang anggarannya belum dicadangkan dan belum dibuatkan perda sehingga berpotensi tidak dapat diselesaikan karena anggaran yang kurang. 
c. Kelemahan Struktur Pengendalian Intern sebanyak 839 kasus terdiri dari:

1. Sebanyak 509 kasus entitas tidak memiliki SOP yang formal atas suatu prosedur

2. Sebanyak 247 kasus SOP yang ada pada entitas tidak ditaati

3. Sebanyak 1 kasus entitas tidak memiliki satuan pengawas intern

4. Sebanyak 55 kasus satuan pengawas intern tidak memadai

5. Sebanyak 25 kasus tidak ada pemisahan fungsi dan tugas memadai

6. Sebanyak 2 kasus pembatasan ruang lingkup audit atas pengelolaan kas daerah

Dari beberapa temuan atas SPI pemerintah daerah tampak bahwa pencatatan dan pelaporan atas aset tetap juga menjadi kasus yang harus direkomendasikan oleh BPK. Hasil rekomendasi BPK ini kemudian harus ditindaklanjuti oleh pemerintah daerah terkait untuk mencapai SPI yang efektif yang pada ahkirnya akan memberikan nilai dalam opini BPK Kep

\section{Kepatuhan terhadap Perundang-Undangan}

Audit atas pemerintah daerah selain untuk tujuan keseuaian dengan Standar Akuntansi Pemerintahan, juga ditujukan atas kepatuhan peraturan perundang-undangan yang berlaku. Temuan pemeriksaan atas kepatuhan perundang-undangan biasanya dikatagorikan berdasar dampak yang muncul akibat dari ketidakpatuhan entitas pemerintahan. Temuan BPK atas LKPD Pemerintah Provinsi di tahun 2011 seperti tabel berikut ini:

Tabel 3 Temuan Ketidakpatuhan terhadap Ketentuan Perundang-undangan

Tahun 2011

\begin{tabular}{|r|l|r|r|}
\hline \multirow{2}{*}{ No } & \multirow{2}{*}{ Kelompok Temuan } & \multicolumn{2}{c|}{ Provinsi } \\
\cline { 3 - 4 } & & Jml Kasus & Nilai (juta Rp) \\
\hline 1 & Kerugian daerah & 216 & $402.190,73$ \\
\hline 2 & Potensi Kerugian Daerah & 40 & $325.894,83$ \\
\hline 3 & Kekurangan Penerimaan & $\mathbf{3 4 3}$ & $52.471,50$ \\
\hline & Sub Total 1 & 21 & $\mathbf{7 8 0 . 5 5 7 , 0 6}$ \\
\hline 4 & Administrasi & 24 & 0,00 \\
\hline 5 & Ketidakhematan & 36 & $147.514,75$ \\
\hline 6 & Ketidakefektifan & $\mathbf{8 1}$ & $\mathbf{2 2 2 . 2 6 5 , 4 3}$ \\
\hline & Sub Total 2 & $\mathbf{4 2 4}$ & $\mathbf{1 . 0 0 2 . 8 2 2 , 4 9}$ \\
\hline & Total & &
\end{tabular}

Sumber :IHPS Semester 1 tahun 2012

Hasil pemeriksaan atas kepatuhan perundangundangan semester 1 tahun 2012 menunjukan kasus-kasus pemeriksaan yang sering terjadi di antaranya adalah permsalahan pengadaan barang/jasa, kekurangan penerimaan dari denda 
keterlambatan pekerjaan serta pengelolaan aset tetap.

Pengelolaan aset tetap menimbulkan potensi kerugian daerah sebanyak 12 kasus dengan nilai sebesar Rp 108.082,01 juta. Kasus pengelolaan aset menempati sekitar $30 \%$ dari total potensi pengelolaan aset. Dengan demikian, pengelolaan aset menjadi masalah yang mengakibatkan opini BPK selain WTP. Kasus pengelolaan aset tetap disebabkan antara lain oleh pejabat yang bertanggungjawab atas aset tetap tidak mentaati aturan yang berlaku dan lemahnya pengawasan serta pengendalian aset. Hal ini mengakibatkan aset tetap milik daerah dimanfaatkan pihak ketika yang mengakibatkan sejumlah aset tetap dimanfaatkan oleh pihak ketiga yang tidak berhak serta dikuasai pihak lain yang tidak sah.

Pengelolaan aset tetap juga menimbulkan kasus administrasi. Temuan administrasi mengungkapkan adanya penyimpangan terhadap ketentuan yang berlaku baik dalam pelaksanaan anggaran maupun pengelolaan aset tetap, hanya saja penyimpangan ini tidak mengakibatkan kerugian daerah atau potensi kerugian daerah dan tidak mengandung unsur indikasi tindak pidana. Penyimpangan terkait aset tetap lainnya adalah kepemilikan aset tetap yang tidak disertai bukti yang tidak didukung bukti yang sah termasuk bukti kepemilikannya.

Potensi kerugian daerah yang cukup besar, administrasi yang masih kacau sehingga tidak ada kepastian secara hukum terkait hak kepemilikan syah atas aset tetap daerah. Atas temuan ini, BPK telah memberikan rekomendasi yaitu kewajiban bagi entitas pemerintah untuk menyelesaikan inventarisasi aset tetap daerah, melakukan pengamanan aset dengan meninjau kembali perjanjian pinjam pakai aset tetap, membuat sertifikat atas tanah milik negara guna menetapkan status aset tetap yang saat ini dikuasai pihak lain.

Dari uraian di atas, maka dapat ditarik kesimpulan bahwa implementasi akrual atas penyajian akuntansi aset tanah di pemerintah provinsi masih mengalami kendala. Besarnya pemerintah provinsi yang mendapatkan opini WTP di tahun 2011 hanyalah sebesar $36 \%$ saja. Dari angka ini menunjukan masih banyak pemerintah provinsi yang belum berhasil mengimplementasikan akrual dalam akuntansi aset tetap, bahkan belum ada separo dari jumlah keseluruhan pemerintah provinsi di Indonesia. Temuan audit menunjukan banyaknya kasus yang menyebabkan potensi kerugian negara yang cukup besar. Kesalahan pengadministrasian aset tetap di pemerintah provinsi juga masih banyak. Hal ini ditunjukan dengan proses inventarisasi aset tetap yang belum selesai hingga saat ini, ketidakjelasan kepemilikan tanah milik pemerintah provinsi serta bukti yang memadai atas aset tetap yang dimiliki pemerintah provinsi.

\section{SIMPULAN}

Implementasi akrual atas akuntansi aset tetap di pemerintah daerah masih jauh dari apa yang diharapkan. Hal ini dibuktikan dengan perbandingan opini BPK atas LKPD Provinsi pada tahun 2011. Opini WTP atas LKPD Provini hanya sebesar $36 \%$ saja dan didominasi oleh opini WDP.

Audit atas efektivitas SPI terkait aset tetap pemerintah daerah menunjukan tidak efektif terutama dalam pencatatan akuntansi aset tetap dan pelaporannya. Hal ini menunjukan rendahnya kemampuan SDM pemerintah daerah atas sistem akuntansi aset tetap di daerah. Audit 
atas kepatuhan perundang-undangan atas aset tetap menunjukan temuan yang mengakibatkan potensi kerugian daerah sebesar $30 \%$.

Selain itu, terkait dengan minimnya pemahaman akan peraturan perundang-undangan terkait aktiva tetap juga mengakibatkan temuan penyimpangan administrasi. Dengan demikian, maka perlu perhatian khusus bagi pemimpin daerah provinsi untuk memahami SAP maupun peraturan perundang-undangan terkait dengan aset tetap, beserta dengan rekomendasi BPK untuk perbaikan kualitas laporan keuangan yang ditandai dengan opini WTP.

\section{DAFTAR PUSTAKA}

Bastian, Indra, 2010, Akuntansi Sektor Publik edisi 3, Penerbit Airlannga

BPK, 2012, Ikhtisar Hasil Pemeriksaan Semester $\underline{1 \text { tahun } 2012}$

Caccia dan Steccolini (2006), 'Accounting Change in Italian Local Governments: What's Beyond Managerial Fashion?', Critical Perspectives on Accounting (vol.17), pp. 154-174.

Carlin (2005), 'Debating the Impact of Accrual Accounting and Reporting in Public Sector', Financial Accountability \& Management (vol. 21No.3), pp.309-336.

Carnegie dan West (2005), 'Making Accounting Accountable in the Public Sector', Critical Perspective on Accounting (vol.16), pp.905-928.

Christiaens, J., Reyniers, B., dan Rolle, C. (2010). Impact of IPSAS on Reforming
Governmental Financial Information Systems: A Comparative Study. International Review of Administrative Science. Vol. 76, No. 3, pp 537-554.

Christiaens, J., dan Rommel, J, (2008), 'Accrual Accounting Reforms: Only for businesslike (parts of) governments,' Financial Accountability \& Management, Vol 24, No 1, pp 59-75.

Christiaens Johan (2003), Accrual accounting reforms in Belgian local governments: A comparative examination Journal of Public Budgeting, Accounting \& Financial Management; Spring 2003; 15, 1; ABI/INFORM Global pg. 92

Halim, Abdul dan Muhammad Syam Kusufi, 2012, Akuntansi Keuangan Daerah edisi 4, Penerbit Salemba Empat

Harun, 2009, Reformasi Akuntansi dan Manajemen Sektor Publik di Indonesia, Penerbit Salemba Empat

Hood, C. (1995). The "New Public Management" in The 1980s: Variations on A Theme. Accounting, Organizations, and Society, Vol. 20, No. 2/3, pp 93-109.

Hoesada, Jan, 2011, Rakernas KASP "Peningkatan Kinerja Pengelolaan Keuangan Pemerintah dalam Rangka Mewujudkan Laporan Pertanggungjawaban Keuangan Pemerintah yang Lebih Berkualitas", September 2011 
Hoesada, Joe, 2009, Dua Puluh Lima Alasan

Penyusutan Penting, Kompilasi Payamta

Lapsley, I., Mussari, R., dan Paulsson, G. (2009). On the Adoption of Accrual Accounting in the Public Sector: A Self Evident and Problematic Reform. European Accounting Review. Vol. 18, No. 4, pp. 719-723. 